\title{
Viability of extended canine semen cooled and storage in a transport container for overnight delivery*
}

\section{Viabilidade do sêmen canino diluído, resfriado e estocado em contêiner para transporte a longa distância}

\author{
Luiz Eduardo Ferreira de Almeida, ${ }^{* *}$ Marcio Ricardo Costa dos Santos ${ }^{\star \star \star}$
}

\begin{abstract}
This study was carried out in order to evaluate the viability of sperm from extended canine semen, cooled and stored at $4^{\circ} \mathrm{C}$ for 24 and 48 hours in a special transport container. The males were stud dogs from different breeds, housed in Niterói and Rio de Janeiro, with an average age of 2.26 years. The examinations were performed in the Animal Assisted Reproduction Laboratory (Reproscenter) at the Veterinary Faculty of UFF. Preliminary breeding soundness of ten dogs gave good results and allowed the animals to be used in the experiment. The averages for the quality of semen immediately after collection were $2 \mathrm{ml} / \mathrm{volume}, 6.5$ pH; $84.5 \%$ motility; 4.2 (RFM); $117.10 \times 10 \% / \mathrm{ml}$ concentration; $91.70 \%$ total live sperm cells (sptz) and $74.7 \%$ normal Sptz. After 24 hours of cooling the averages were $79.0 \%$ motility; 4.3 (RFM); $86.9 \%$ total live sptz; and after 48 hours, $73 \%$ motility; 4.2 (RFM); $79.7 \%$ total live Sptz. The laboratory prepared used extender allowed the sperm to survive for more than 48 hours after collection from the stud dog. As soon as the semen is collected, evaluated and placed in the extender, it can then be shipped in this special container, cooled at $4^{\circ} \mathrm{C}$, for overnight delivery. Data of this experiment provides guidelines to perform a technique using fresh cooled canine semen, storage at $4^{\circ} \mathrm{C}$, during 48 hours, in a shipping container.
\end{abstract}

Keywords: Chilled semen, transport, canine.

\section{Resumo}

Este trabalho foi desenvolvido para avaliar a viabilidade espermática de sêmen canino diluído, resfriado e armazenado a $4^{\circ} \mathrm{C}$, durante 24 e 48 horas em contêiner especial para transporte. No Laboratório de Reprodução Animal Assistida (Reproscenter), na Faculdade de Veterinária da UFF foram selecionados para a avaliação de seus ejaculados 10 reprodutores, com média de idade de 2,26 anos, provenientes de canis da região de Niterói e Rio de Janeiro. As médias das amostras de sêmen avaliadas, imediatamente após a colheita foram: $2 \mathrm{~mL} /$ volume; $6,5 \mathrm{pH} ; 84,5 \%$ motilidade; 4,2 vigor; $117,1 \times 106 / \mathrm{mL}$ concentração; $91,7 \%$ total espermatozóides (sptz) vivos e 74,7\% sptz normais. Com 24 horas após o resfriamento as médias foram de $79 \%$ motilidade; 4,3 vigor e $86,9 \%$ total sptz vivos. Com 48 horas, $73 \%$ motilidade; 4,2 vigor e 79,7 sptz vivos. O diluidor utilizado foi preparado no Laboratório e permitiu que os espermatozóides sobrevivessem por mais de 48 horas após a colheita do cão reprodutor. Assim que o sêmen é colhido, avaliado e diluído, é colocado no contêiner e resfriado a $4^{\circ} \mathrm{C}$ durante 24 e 48 horas. Os resultados deste experimento fornecem orientação para a técnica de utilização de sêmen canino resfriado e armazenado a $4^{\circ} \mathrm{C}$ durante 48 horas em contêiner, para transporte a longa distância.

Palavras-chave: Sêmen refrigerado, transporte, canino.

\section{Introduction}

The increase in low fertility in the canine species is the principal consequence of a badly guided selection process for breeding and reproductive stock, based only on phenotypic characteristics and on the functional performance of these animals. As well as this negative selection for reproduction there are many other reasons why canidae fail in conception. An important component of fertility is good quality of semen, especially when artificial methods of assisted reproduction are used, such as artificial insemination.
The use of canine semen conserved at a low temperature is still not a common procedure, although throughout the world increasing interest in its use has been demonstrated since Harrop $(1954,1956)$ reported the birth of the first progeny from dogs using artificial insemination with preserved semen. Interest in the use and shipping of canine semen has stimulated the creation of private institutions with semen banks which can provide a genetic pool which in turn can be used, in small geographically isolated populations, in order to avoid consanguinity, eliminate hereditary diseases, or simply to shorten the distance between desirable coverage.

\footnotetext{
* This work had the support of a CAPES masters grant.

" DVM, MSc, Veterinary Clinic Pet in Rio, Rio de Janeiro, RJ.

"*t DVM, MSc, PhD, Prof. Dep. Vet. Clin. Pat. UFF, Niterói, RJ. mrcosta@doutor.com.br/ reproscenter@caixapostal.com.br
} 
In the United States and in Europe artificial insemination in canine specie is systematically performed, with excellent results. The high incidence of infertility amongst males has provided an additional impulse to this practice. Cooled semen, does not significantly alter the survival of spermatozoids in the dog, therefore is the most recommended method for artificial insemination of this species. Nonetheless, there is little information about the methods of transport of cooled canine semen capable of ensuring the success of artificial insemination with a good rate of conception. Therefore, the objective of this experiment was to determine the viability of canine semen 24 and 48 hours after being extended and submitted to cooling in a container for transport. Furthermore, the results provide information to divulge the technique and to establish an increase in the routine of artificial insemination with cooled semen in kennels in Rio de Janeiro-Brazil.

\section{Material and methods}

Ten healthy stud dogs from the breads Beagle (1), Cocker Spaniel (1), Deutsche (2), Fila Brasileiro (1), Poodle (3) and Rotweiller (2), aged between 1 to 5 years old, were used as semen donors. The males came from breeders in the regions of Niterói and Rio de Janeiro, with their handling on the properties where they lived having been observed. Dogs were taken to the Assisted Animal Reproduction Laboratory (Reproscenter) in the Veterinary College of UFF, or to the veterinary clinic Pet in Rio, for andrological examination and the collection of samples. The data referring to the animals used, to the collection and to the examination of the semen were registered on the andrological examination file.

For the collection of the semen from the dogs, all the material used was pre-heated and maintained at $37^{\circ} \mathrm{C}$, to avoid thermal shock. The ejaculations were obtained by digital manipulation and collected in accordance with the technique described by Almeida (1998) in a marked glass tube with a $10 \mathrm{~mL}$ capacity. In order to reduce the third prostatic fraction collected, the total volume to be used was standardized at $2 \mathrm{~mL}$.

After the collection, and during the initial analyses, the semen was kept simmering at $37^{\circ} \mathrm{C}$, for a maximum interval time of 10 minutes, until the moment of cooling. Physical, macro and microscopic characteristics were observed: volume, colour, odour, density, motility, vigour and concentration. The spermatic morphology and the percentage of live sperm cells were evaluated according to Milward (2002).

Each sample was extended to $1: 2$, with a laboratory prepared solution of skimmed milk, antibiotics and glucose until the final volume of $6 \mathrm{~mL}$ was obtained, following the methodology of Santos et al. (2002). The extended semen, simmering at $37^{\circ} \mathrm{C}(0 \mathrm{~h})$, was divided into two equal parts for cooling. The volume of each part was corrected with the same extender to 6 $\mathrm{mL}$, into two class tubes $\left(T_{1}\right.$ and $\left.T_{2}\right)$, which were immediately incubated in the transport Container for cooling, with a thermal exchange system, which allowed a precise rhythm in the decline of temperature, from 37 to $4^{\circ} \mathrm{C}$ in 10 hours (Hamilton Thorm Equitainer, Massachusets, USA).

The data was obtained from the analysis carried out in accordance with the time semen had been cooled. Ejaculate were analyzed in three moments after being extended with non-parametric methods, for tabular analysis, to obtain the averages and the standard-deviation of the values, with the determination of the statistical significance. The samples evaluated just after being extended (0h), still at $37^{\circ} \mathrm{C}$, constituted group 1 and the samples after 24 and 48 hours of cooling constituted groups 2 and 3 respectively.

\section{Results and discussion}

The results obtained support the previous observation (Almeida, 1998; Santos et al., 2002; Milward, 2002) that maintenance of canine semen, extended with a solution of skimmed milk, glucose plus antibiotics and, kept at $4^{\circ} \mathrm{C}$ for a period of 48 hours is viable, without compromising the capacity of the spermatozoids to fecundate. The ten semen samples analysis, illustrated in Figure 1, had as sources of variation the motility, the vigor and the total of live spermatozoids (sptz) in function of the groups (1, 2 and 3), according to the time of cooling in the transport container. Upon evaluating the behaviour of the variables, it was observed that in relation to the cooling (24 and 48 hours), the total of live normal spermatozoids was still good after 48 hours, as also observed by Aguiar et al. (1994), Linde-Forsberg (1995), England and Ponzio (1996). This condition, inherent to the cooling process of the semen, extended in a solution of skimmed milk, antibiotics and glucose (Santos et al., 2002), is compatible with the maintenance of a large percentage of the live spermatozoids, supports the opinion and corroborates the conclusions of other researchers (Rota, 1995, Farstad, 1996; Threfall, 1996; Silva et al, 1996; Cunha and Lopes, 2000) in which cooled extended semen had a short period of life, but which was sufficient to maintain its fertility for more than 72 hours (Iguer-Ouada and Verstegen, 2001).

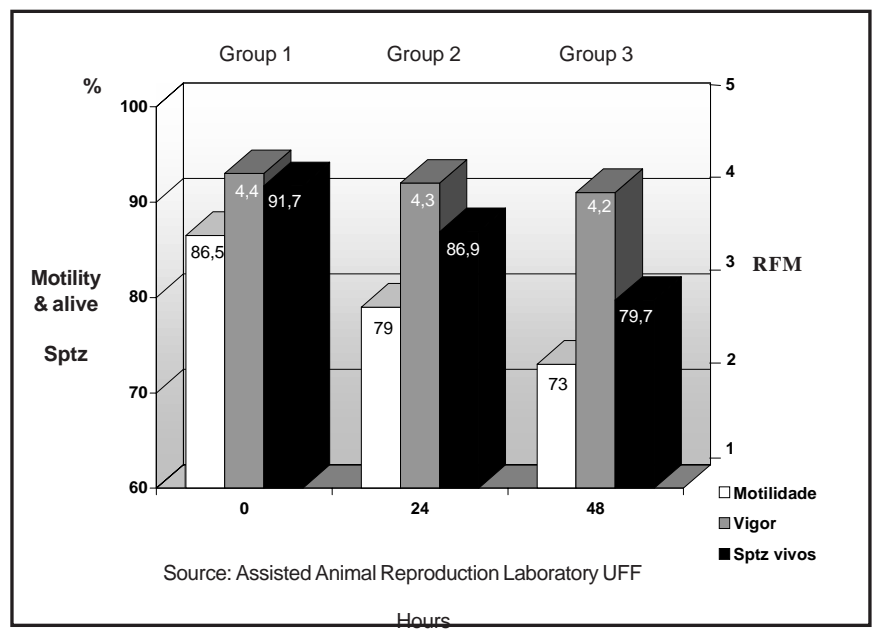

Figure 1: Average values for motility, vigour and alive sptz in 10 samples of canine semen, before and after cooling, according to the studied groups

The total ejaculated volume obtained should not be evaluated in the present study, because only the first and second fractions were collected $( \pm 2 \mathrm{ml})$. The third fraction, composed for the most part of prostatic fluid, was discarded, while in other studies (Farstad, 1996; Paulenz, 1993) the three fractions were collected integrally. No negative influence of the prostatic fluid occasionally collected was observed on the semen quality or 
results, due to the use of an extender in a solution of skimmed milk with glucose (Santos et al., 2002), within a maximum of 10 minutes after collection, with a similar action to that observed by other researchers (Rota et al., 1995; Cunha and Lopes, 2000). An opalescent white colour appeared in 7 of the 10 ejaculations which varied from dense to semi-dense, directly proportional to spermatic concentration $\left(117.1 \pm 10.39 \times 10^{6} / \mathrm{ml}\right)$, above the parameters evaluated by Cunha and Lopes (2000), who obtained $63.9 \pm 45.46 \times 10^{6} / \mathrm{ml}$ per ejaculation, and by Aguiar et al. (1994) who calculated around $47.73 \pm 12.2 \times 10^{6} / \mathrm{ml}$, for dogs of up to $20 \mathrm{~kg}$ live weight.

The average initial motility $(86.5 \pm 1.88 \%)$ observed in the experiment was superior to that observed by other authors (Aguiar et al., 1994; Cunha and Lopes, 2000) who found $68.91 \pm 12.38 \%$ and $74.4 \pm 8.92 \%$ respectively. Spermatic vigour observed immediately after collection $(4.4 \pm 0.22)$ also presented values superior to the $3.19 \pm 0.76$ and $3.68 \pm 0.69$, found by the researchers (Aguiar et al. 1994, Cunha and Lopes, 2000) respectively. After 24 and 48 hours (groups 2 and 3 ) only the variable vigour continues to maintain itself with practically the same intensity. The variable assumes a much less acute line of reduction, without significant values, in a similar way to that of previous observations (Morton and Bruce, 1989; Farstad, 1996; Paulenz, 1993, Cunha and Lopes, 2000; Iguer-Ouada and Verstegen, 2001).

In relation to the total live spermatozoids and morphology, the results of group 1 were within the normal parameters for the canine species (Threlfall, 1996; Almeida, 1998). In relation to alterations in spermatic morphology, no significant differences $(p=0.05)$ were found in relation to the highest and lowest

\section{References}

AGUIAR, P.H.P; COSTA, M.E.L.T; ABREU, J.J; ABREU, C.P. Coleta e avaliação de sêmen canino. Arq.Bras.Med.Vet.Zoot., v. 46, n. 5, p. 537-544, 1994.

ALMEIDA, L.E.F. Viabilidade espermática do sêmen de cães, nas 24 e 48 horas após diluição e resfriamento em container para transporte. Niterói, 1998, 40 p. (Masters Dissertation in Veterinary Medicine, Faculty of Veterinary Medicine of UFF), 1998.

CUNHA, I. C. N. \& LOPES, M.D. Estudo do processo de refrigeração do sêmen canino utilizando-se diluidores à base de leite e glicina-gema. Rev.Ed.Cont.CRMV-SP., v. 3, n. 1, p. 37-42, 2000.

ENGLAND, G.C.W..; PONZIO, P. Comparison of the quality of frozen thawed and chilled-reheated dog semen. Theriogenology, v. 46, n. 2 , p. 165-171, 1996.

FARSTAD, W. Semen cryopreservation in dogs and foxes. An.Reprod.Science, v. 42, p. 251-260, 1996.

HARROP, A.E. Artificial insemination of a bitch with preserved semen. Vet.Rec., v. 112, p. 338-340, 1954.

HARROP, A.E. Artificial insemination in dogs, the first transatlantic conception. Brit.Vet.J., v. 112, p. 338-340, 1956.

IGUER-OUADA, M.; VERSTEGEN, J.P. Long term preservation of chilled canine sêmen effect of commercial and laboratory prepared extenders. Theriogenology, v. 55, p. 671-684, 2001.

KUMI-DIAKA, J.; BADTRAN, G. Effect of Storage on Sperm Membrane Integrity and other Functional Characteristics of Canine Spermatozoa: in vitro Bioassay for Canine Semen. Theriogenology, v. 41, n. 7, p. 1355-1366, 1994. percentage of defects, among both the initial evaluations and those after 48 hours of cooling. The highest amount of defects observed were, a majority of times in groups 2 and 3, related to alterations in the permeability of the membrane or to thermal shock. These pathologies are compatible with those cellular damages, which occur during the reduction of temperature over a prolonged period of time (Morton and Bruce, 1989; Paulenz, 1993; Kumi-Diaka and Badtran, 1994; Farstad, 1996; Milward, 2002).

\section{Conclusions}

The cooling of the canine semen, from 37 to $4^{\circ} \mathrm{C}$ in a transport container is a safe technique, easy to carry out, which can be used by veterinarians in clinics and breeding kennels, with the minimum of equipment, and without the used dogs suffering from any kind of discomfort or rejection.

Under the conditions of the present study the cooling and maintenance of extended canine semen at $4^{\circ} \mathrm{C}$ in the container was viable, with a possibility of immediate transport, and the clinic could arrange to send the semen to distances up to 48 hours away for its use.

The group effect showed itself to be significant for the quality of the sample, in relation to the gradual reduction of motility and spermatic vigour, according to the experimental delineation. However, more studies are necessary to use the cooled samples in the artificial insemination of bitches from Rio de Janeiro, in order to evaluate the in vivo fecundity capacity of treated spermatozoids.

LINDE-FORSBERG, C. Artificial insemination with fresh, chilled extended and frozen-thawed semen in dog. Semin. Vet.Surg.Small.An., v. 10, p. 58, 1995.

MILWARD, C.O. Efeito do resfriamento a $4^{\circ} \mathrm{C}$ sobre as características físicas e morfológicas do sêmen de cães, diluído e mantido durante 48 horas em container para transporte. Niterói, 2002, 63 p. (Masters Dissertation in Veterinary Medicine, Faculty of Veterinary Medicine of UFF), 2002.

MORTON, D.B.; BRUCE, S. G. Semen evaluation, cryopreservation and factors relevant to the use of frozen semen in dogs. J.Reprod.Fert. Suppl., v. 39, p. 311-316, 1989.

PAULENZ, H. Spermiemembranes struktur og funksjon i relasjon til kudesjokk. Norw.J.Vet.Med., v. 105, p. 1135-1142, 1993.

SANTOS, M.R.C.; ALMEIDA, L.E.F.; QUEIROZ, F.J.R. Meio extensor para manutenção de sêmen canino resfriado em contêiner para transporte a longa distância. Rev.Brás.Cien.Vet., v. 9, n. 2, p.83-85, 2002.

SILVA, L.D.M.; ONCLIN, K.; LEJEUNE, B.; VERSTEGEN, J.P. Comparasions of intravaginal and intrauterine insemination of bitches with fresh or frozen semen. Vet.Rec. v. 138, p. 154-157, 1996.

ROTA, A.; STROM, B.; LINDE-FORSBERG, C. Effects of seminal plasma and three extenders on canine semen stored at $4^{\circ} \mathrm{C}$. Theriogenology, v. 44, p. 886-900, 1995.

THRELFALL, W. R. Semen Collections and semen shipment. In: Canine Reproduction Short_Course. Theriogenology, Ohio State University, USA, p. 42-48, 1996. 